\title{
Strengthening Local Economy through Tourism Village: Case Study in Dukuh Dalem, Sleman Regency
}

\author{
Ali Roziqin ${ }^{2}$, Adejaya $\mathrm{MS}^{3}$, Khadir $\mathrm{Ali}^{4}$
}

\begin{abstract}
Tourism destination "blue lagoon" contained in dukuh dalem, widodomartani village, District of Ngemplak, Sleman Regency was not many people who know. But, since of 2014, starting from one of student, who updates photos from the river. Then it is be viral (popular) and tourist attraction. The research uses descriptive qualitative methods which data was collected from indepth interview, observation, and literature study. The result is inisiator role can driven to several stakeholders to create tourism village based on-water resources. In addition, management of turism village be supported by any stakeholders such as, governments, community, and private sector. Another effect is tourist attraction "blue lagoon" has become a multiplier effect for the wheels of the village economy. It also contributes productively to community empowerment. Lesson from the case, the neverending innovation and collaboration become the key to success to attract tourists to visit the "blue lagoon" tour.
\end{abstract}

Keywords: Tourism Village, Blue lagoon, Local Economy.

\section{Introduction}

Poverty and unemployment is always identical in Indonesian village. Oftenly, the village can not develops and running as a stagnant. The village seems to be second priority in development matters. Whereas, the village is one most powerful to create Indonesia advancement. Some programs dan policys to development on village has arrangement and implemented. However, it's resuls not yet like a hope. This condition is caused by various things. Starting from Human Resources Management (HRM) are indadequate. limited natural resources (natural resources) and the traditional mindset of the villagers. Besides that, there is also irony, where productive forces in the village decide to go to the city to get a better life. Finally, in the village, most of it is inhabited by unproductive elderly / elderly people. This phenomenon is often called urbanization.

Urbanization flows in Indonesia have yet to stop. One of the causes is the existence of development inequality in cities and villages. As long as development is not evenly distributed, urbanization flows are predicted to never stop. However, from some village phenomena, there are several rural areas in Indonesia that can empower natural resources that are owned by integrating existing human resources. One phenomenon that is developing at this time is a tourist village. The development of this tourism village is also supported by the Village Law, in which the village is given the authority to empower the community and advance its area. Therefore, in this study, the author will raise the issue of how successful a hamlet or village has succeeded in developing a tourist village, namely the "blue lagoon" tourist village, dukuh dalem, Widodomartani village, Ngemplak district, Sleman regency.

The village dalem is a village around the slopes of Merapi. Like the conditions of other villages on the slopes of Merapi. This village, most of the majority of the people are engaged in the agricultural sector with a large enough rice field. Overall in Sleman Regency in 2015 the agricultural sector absorbed 123,073 people or $23.02 \%$ of the working population (Sleman, 2016). The agricultural sector that is cultivated by the majority of the Widomartani villagers

1,2, 3 Student at Magister of Public Administration, UGM 
does not seem to have a good impact on the economy of the community. Besides being dependent on natural conditions, the agricultural sector takes a long (traditional) time in the harvest process and the results on the market are uncertain. So that the youths are reluctant to enter this sector.

However, the conditions of agriculture and nature that are still traditional in Widomartani village turned out to save a lot of potential for development. This potential is believed to make its own attraction for tourists if it is used as a tourist village. The village potential is quite abundant with a source of springs, it is a pity not to be used for the common interest. That reason then moves some people to initiate a tourism village based on springs. With this tourism village, it is hoped that it will become a multiplier effect and bring prosperity to the surrounding community.

This potential is also supported by data that states that the Special Region of Yogyakarta still ranks second as the main tourist destination in Indonesia after Bali (Hermawan, 2016). Recorded number of tourist visits increased by 472,300 tourists per year, with an average length of stay of 1.5 to 2 days (Dinas Pariwisata, 2014). While the labor force in Sleman Regency is also quite a lot with the open unemployment rate of $6.12 \%$.

Table 1.1

Employment Development in 2011-2015

Sleman Regency

\begin{tabular}{|l|l|l|l|l|l|l|}
\hline No & Description & $\mathbf{2 0 1 1}$ & $\mathbf{2 0 1 2}$ & $\mathbf{2 0 1 3}$ & $\mathbf{2 0 1 4}$ & $\mathbf{2 0 1 5}$ \\
\hline 1 & $\begin{array}{l}\text { Working Age } \\
\text { Population }\end{array}$ & 782.251 & 939.463 & 875.102 & 861.472 & 829.355 \\
\hline 2 & Workforce & 524.326 & 560.378 & 541.921 & 560.772 & 569.584 \\
\cline { 2 - 7 } & Work & 484.405 & 522.622 & 506.862 & 526.171 & 534.725 \\
\cline { 2 - 7 } & Open unemployment & 39.921 & 37.754 & 35.059 & 34.601 & 34.859 \\
\hline 3 & Not the Labor Force & 257.925 & 379.087 & 333.181 & 300.700 & 259.771 \\
\hline 4 & TPAK & $67,03 \%$ & $59,65 \%$ & $61,93 \%$ & $65,09 \%$ & $68,68 \%$ \\
\hline 5 & $\begin{array}{l}\text { Unemployment Rate } \\
\text { Open }\end{array}$ & $7,61 \%$ & $6,74 \%$ & $6,17 \%$ & $6,12 \%$ & $6,12 \%$ \\
\hline
\end{tabular}

Source: RPJMD Sleman Regency, 2016

The large number of workforce and limited employment opportunities were also felt in Ngemplak Village, Sleman Regency. Therefore, with the development of tourist villages in this case "blue lagoon" is expected to be able to move the economy of the local community. Besides that the existence of blue lagoon can add alternative tourism sources for traditional springs in the DI Yogyakarta area. Based on the problems, authors aims to explore how is innovation process the emergence of blue lagoon tourism villages and their impact on local communities

This paper uses a descriptive qualitative approach that is research that aims to describe or describe certain social phenomena (Singarimbun and Effendi, 1989). To obtain data, the researchers did the following: in-depth interviews (Indepth Interview) to 2 informants. 
Furthermore, observation to observe directly the conditions around the object of research and literature review related to the development of tourism villages.

The tourism sector in the framework of village development is an alternative to improve the welfare of local communities (Hariyanto, 2016). This is a kind of success in developing tourism if it is able to consolidate the progress of the village. While tourism development is considered to be a failure if the benefits of tourism activities are actually enjoyed by outsiders. Conceptually, tourism is a variety of tourism activities that are supported by various facilities and services provided by the community, entrepreneurs, local governments.

Tourism village according to (Hermawan, 2016) is an area in the form of a rural environment that has a tourist attraction based on local wisdom such as customs, culture, and natural wealth that has a uniqueness and authenticity in the form of a characteristic rural atmosphere. Rural areas that are managed as tourist villages usually have more than one or a combination of several tourist attractions (Tourism Law No.10 of 2009). The development of rural-based tourism areas is a potential that is very likely to become a leading in the future. The tourism village development requires good management from all stakeholders.

The principle of implementing good tourism governance is the coordination and synchronization of programs between stakeholders and the involvement of active participation among stakeholders in the community. Theoretically the management pattern of the implementation of sustainable tourism development according to (Sunaryo, 2013) is as follows:

1. Community participation: Local people must monitor or control the existing tourism development by participating in determining the vision, mission and objectives of tourism development, identifying resources that will be developed and utilized for the development and management of tourist attractions.

2. Involvement of all stakeholders: Must involve NGOs, volunteers, local governments, tourism industry associations, business associations and other parties who will receive benefits from tourism activities.

3. Partnership on local ownership: Existing tourism potential should belong to local communities, with ownership of the community will benefit and be deceived as a whole.

4. Continuous use of resources: Utilization of resources is not exploited arbitrarily by irresponsible interests.

5. Accommodating people's aspirations: Community aspirations will be an important input related to what the community needs.

6. Environmental carrying capacity: Maintaining environmental support capacity for the present to the future.

7. Monitor and evaluate the program: Monitor and evaluation function to assess and improve in a better direction.

8. Environmental accountability: The existence of these tours will not have a negative impact on the surrounding environment. The carrying capacity of the environment is maintained and is stable for all elements of living things.

9. Training in related communities: to create new innovations and competencies, training needs for local communities to support the existence of these tourism.

10. Promotion and advocacy of local cultural values: promoting local culture. 


\section{Discussion}

Every change, every burst of creativity, begins with identification of a problem or opportunity that somebody finds meaningful" Margareth J, Wheatley (Wheatley, 2001). The beginning of a change is to begin by identifying existing problems and possible opportunities to be optimized. That is roughly the sentence that can describe the process of an "ordinary time" in the village, and be changed into a tourist destination that is able to move the economy of the local community. With the existence of new tourism objects in the dalem dalem, the community gets the advantage of the average income of the community that has increased (Sulistiyowati, 2017). Therefore, the process of change will be discussed in the "blue lagoon journey", dukuh dalem in Widodomartani village with the indicators in the previous literature review

\section{A. Society Participation}

The blue lagoon tourism was launched on Marh 22, 2015 by The Regent of Sleman Regency, Mr. Sri Purnomo. The tourism is based on natural water resources in the village. In the past, this place used as a place to public bathing, washing, and toilet facilities for community. But, everythings has changed when students who do real work lectures in this area take selfies, and the students named it "blue lagoon". The term blue lagoon itself is a term from students, because it looks at the nature of water that often changes depending on the lighting from the sun. Previously, the surrounding community called this river with various designations such as: Tepus river, dam tempel, sendang tulungan, and tirta budi.

Seeing this opportunity, Mr. Suhadi (inisiator) and several other hamlet leaders communicated to other residents and got the enthusiasm of most residents. Although there was an antipathy by some residents who from "office employees", but finally most people agreed. The potential of natural resources that exist and the human resources that are here is very possible if used as a tourist village. All members of the community agreed to create a tourist village, then we formed an organizational committee, after it was formed, then Mr. Suhadi was given the mandate to become the head of the village tourism manager. The development of tourism village also involve all stakeholders to work together.

\section{B. Stakeholder Involvement}

The process of establishing a "blue lagoon" tourism village was the result of the collaboration and support of several stakeholders. The collaboration is most important to develop everythings in the community. Collaboration is the act or process of "shared creation" or discovery. It involves the creation of new value by doing something new of different (Thompson and James, 2006)

The officer of tourism village have collaborated with government to create a tourism village. The officer needs the time approximately 3-6 months. On September 2014 we started the tourism village formation, the tourism village was become the $7^{\text {th }}$ winner in the Sleman Tourism Village.

In this case, the distric government supports to Mr. Suhadi (Inisiator and Leader) for development of human resources and management mechanisms. Through tourism and 
natural resources office gives directives and direction such as coaching and training through the organization OPPM (farmers and managers of water resources). Meanwhile, from Tourism Departement build a POKDARWIS (Tourism Awarenes Group) to concern about human resources management.

Seeing this presentation, there is an interesting thing that for the development of this tourism the percentage is quite balanced between the government and the pro-active community. Apart from that, since 2015 this tourist attraction received an injection of village funds for its development. Although the disbursement and funding mechanism is not specified in detail by the manager. The manager underlines the submission of funds to the government, either district or village, only if it requires substantial funds. The rest of tourism development is the result of operational funds obtained from visitors (tickets).

\section{Partnership for local ownership}

The development of "blue lagoon" tourist attractions and villages is managed independently by the surrounding communities in dukuh dalem. Some concerned citizens set themselves up to fight together to develop "blue lagoon" tourism. The beginning of working here is only 8 people, weekly only get $20-25$ thousand per week per person. Slow but sure, steps by steps produce outputs. This place is famous tourism in Yogyakarta. On the other hand, the development of blue lagoon tourism is the joint responsibility of the dukuh dalem community. So that people feel they have this potential. In addition, there are also many people who have relied on the economic existence of this object. So the people feel possessed.

\section{Resource utilization continues}

Not only limited to being a tourist attraction, the existence of this spring is also used by residents for their rice irrigation systems. So that between tourism objects and irrigation systems can run together without any interference with each other. In addition, the water system around the blue lagoon is used by the community for fisheries. Therefore, in our observations, visitors are prohibited from throwing garbage in the river. At the same time it is prohibited to use chemicals such as bath soap, shampoo, detergent and others to preserve the environment around the river.

\section{E. Accommodate the aspirations and culture of the community}

From the initial formation to the process of developing tourism villages, people are always involved in decisions. Even there is an element of local culture that is always commemorated every year at the suggestion of the community so that culture remains inherited and not lost. All aspiration received as a making policy process to improvement tourism village.

\section{F. Environmental carrying capacity}

As an environment-based tourism object and water source. When we visit the tourist site, there is only one or two garbage bins provided by the manager. This is certainly feared that it will cause waste. Especially if visitors are recognized by the manager as a common obstacle

\section{G. Monitoring and evaluating programs}


To maintain the existence of tourism objects, managers always monitor and evaluate whatever is lacking and need improvement. Physically, every week we must always change from the manager even though it's only limited to repairing the hut or the other, every month there must be a change and every year there must be a change in a better direction. We used to make the gazebo, because we were still self-supporting in the race per RT making two. And now we have about 8 gasebo around the object destination.

Improvements and innovations made by the management need to be appreciated. In 2017 the authors visited this object, there was only one gazebo and that was not enough. In addition, related to the arrangement of the entrance and exit which have not been arranged in such a way. These changes certainly aim to improve services to tourists.

\section{H. Training in the community}

The manager or head of tourism village (Dukuh Dalem) has a plan to provide training for mothers. This innovation purposed to create handicrafts from batik, souvenirs, culinary, and etc. Escpecially for young people concerned on art and craft. This plan is certainly very progressive to increase the prestige of blue lagoon tourism, as well as being an additional input for citizens to increase their income.

\section{Promotion and advocacy}

The advocacy process continues, even when the manager plans to open a homestay or lodging. Managers think that in dukuh dalem there are many elderly or elderly people. When they are left by their children, their parents live alone with homes that are too big, why not use the house as an inn that is grouped as a homestay. Because it also intends to improve their welfare as well. Furthermore, the tariff charged for visitors is per night 350 thousand. In certain periods such as school holidays and Eid al-Fitr stay can reach 100150 people.

\section{Conclusion}

"Making innovation everyone's job intuitively appealing but very hard to achieve" Julian, 2011). Every changes and innovations need to hard work and somehow difficult. The success of "blue lagoon" to become a new tourist distortion in Sleman Regency can not be separated from initiators who have a vision far ahead. It is also supported by the environment such as active community participation. Hard work and the desire to change a condition are the starting points that need to be underlined. Even though in brief there is no one central figure like a leader, but the existence of a "small team" is enough to move all the potential that exists. Although at first there was resistance from some people, as time went on, the initiation of the small team slowly began to show results. Furthermore, it is supported by a commitment by the manager and the community not to stop making improvements and changes in tourist attractions. So that it always brings its own added value and visitors are satisfied with the services provided.

The existence of a tourism village in dukuh dalem, a "blue lagoon" tourist attraction, has a positive impact on local economy in the community. Such as trade, lodging and other economic activities. The existence of a "blue lagoon" as a tourism village is able to move the economic wheel of society. So that the village slowly moves forward. This is a kind of 
benchmarking for other villages interested in developing the potential of villages (tourist villages). Moreover, the government has supported the existence of village funds for each village. So that the ideals of achieving a just and comprehensive prosperity will be realized.

\section{References}

Dinas Pariwisata, D. (2014). Statistik Kepariwisataan 2014. DI Yogyakrta.

Hariyanto, O. (2016). Destinasi Wisata Budaya dan Religi di Cirebon. Ecodemica, Volume 4 issue 2, 214-222.

Hermawan, H. (2016). Dampak Pengembangan Desa Wisata Nglangeran terhadap Ekonomi Masyarakat Lokal . Pariwisata, Volume 3 no. 2, 105-117.

Julian, B. e. (2011). The 5 Myths Innovation. MIT SLOAN MANAGEMENT REVIEW, 43.

Singarimbun dan Effendi, S. (1989). Metode Penelitian Survei. Jakarta: LP3ES.

Sleman, B. K. (2016). RPJMD Kabupaten Sleman 2016-2021. Selman: Kabupaten Sleman.

Sulistiyowati, A. (2017). Dampak Keberadaan Desa Wisata Blue Lagoon terhadap Pendapatan Masyarakat di Dusun Dalem Desa Widodomartani, Kecamatan Ngemplak, Kabupaten Sleman 2017. Yogyakarta: Tidak diterbitkan.

Sumodinigrat, G. d. (2016). Membangun Indonesia dari Desa. Yogyakarta: Media Pressindo.

Sunaryo, B. (2013). Kebijakan Pembangunan Destinasi Pariwisata: Konsep dan Aplikasinya di Indonesia . Yogyakarta: Gava Media.

Thompson and James, A. M. (2006). Collaboration Processes: Inside the Black Box. Public Administration Review, 20-32.

Wheatley, M. J. (2001). We Are All Innovations. In M. G. Frances Hesselbein, Leeading for Innovation: and Organizing for Results (pp. 11-21). San Fransisco: Josseybass. 